\title{
IMPLEMENTASI KEBIJAKAN PENYELESAIAN PERSELISIHAN HUBUNGAN INDUSTRIAL MELALUI MEDIASI DI INDONESIA (STUDI KASUS: KABUPATEN SUMEDANG)
}

\author{
Friska Prastya Harlis ${ }^{1}$, Herwan Abdul Muhyi ${ }^{2}$, Mohammad Benny Alexandri ${ }^{3}$ \\ friska.p.h@gmail.com ${ }^{1}$, herwan_am@yahoo.com ${ }^{2}$, mohammad.benny@unpad.ac.id ${ }^{3}$ \\ Program Pasca Sarjana Kebijakan Publik \\ Fakultas Ilmu Sosial dan Ilmu Politik \\ Universitas Padjadjaran
}

\begin{abstract}
ABSTRAK
Penelitian ini bertujuan untuk mengetahui mengapa implementasi kebijakan penyelesaian perselisihan hubungan industrial melalui mediasi di Indonesia dengan studi kasus di Kabupaten Sumedang yang dilaksanakan oleh Dinas Tenaga Kerja dan Transmigrasi Kabupaten Sumedang belum efektif. Metode yang digunakan dalam penelitian ini adalah metode penelitian kualitatif bersifat deskriptif dan cenderung menggunakan analisis dengan pendekatan induktif. Dimana dengan melalui metode kualitatif, peneliti berusaha mencari pemahaman terhadap suatu objek. Dari hasil penelitian diketahui bahwa implementasi kebijakan penyelesaian perselisihan hubungan industrial melalui mediasi yang dilaksanakan oleh Dinas Tenaga Kerja dan Transmigrasi Kabupaten Sumedang belum efektif karena belum terpenuhinya variabel ukuran dan tujuan kebijakan, sumber daya, karakteristik agen pelaksana, sikap para pelaksana, aktivitas implementasi dan komunikasi antar organisasi serta lingkungan ekonomi, sosial dan politik.
\end{abstract}

Kata Kunci : Implementasi Kebijakan, Penyelesaian Perselisihan Hubungan Industrial, Mediasi, Indonesia

\begin{abstract}
This study aims to find out why the implementation of industrial relations dispute resolution policies through mediation in Indonesia with a case study in Sumedang District carried out by the Sumedang District Manpower and Transmigration Office has not been effective. The method used in this research is descriptive qualitative research methods and tends to use analysis with an inductive approach. Where through qualitative methods, researchers try to find an understanding of an object. From the results of the study note that the implementation of industrial relations dispute resolution policies through mediation carried out by the Department of Manpower and Transmigration of Sumedang Regency has not been effective because of the unfulfilled variable size and policy objectives, resources, characteristics of implementing agencies, attitudes of the implementers, implementation activities and communication between economic, social and political organization and environment.
\end{abstract}

Keywords: Policy Implementation, Industrial Relations Dispute Settlement, Mediation, Indonesia

\section{PENDAHULUAN}

Kebijakan

ketenagakerjaan

merupakan hal yang penting untuk dibuat dan diterapkan. Di Indonesia, masalah ketenagakerjaan masih sangat memprihatinkan. Kurang harmonisnya hubungan industrial, sejumlah bentuk perselisihan antara pekerja dan pengusaha 
IMPLEMENTASI KEBIJAKAN PENYELESAIAN PERSELISIHAN HUBUNGAN INDUSTRIAL

MELALUI MEDIASI DI INDONESIA

(STUDI KASUS: KABUPATEN SUMEDANG)

(Friska Prastya Harlis, Herwan Abdul Muhyi, Mohammad Benny Alexandri)

yang meliputi masalah upah, kecelakaan kerja, jam kerja dan yang melanggar norma ketenagakerjaan. Situasi ini dikenal dengan perselisihan hubungan industrial. Mengenai perselisihan hubungan industrial di dunia ketenagakerjaan ini, Pemerintah Indonesia mengeluarkan kebijakan mengenai Penyelesaian Perselisihan Hubungan Industrial melalui Undang-Undang Nomor 2 tahun 2004 tentang Penyelesaian Perselisihan Hubungan Industrial. UndangUndang Nomor 2 Tahun 2004 tentang Penyelesaian Perselisihan Hubungan Industrial mengatur bagaimana cara menyelesaikan perselisihan hubungan industrial.

Kabupaten Sumedang merupakan salah satu Kabupaten yang berada di wilayah Provinsi Jawa Barat yang tepat berada di tengah-tengah Provinsi yang menghubungkan Kota dan Kabupaten yang akan menuju ke ibu kota Provinsi Jawa Barat yaitu Kota Bandung. Dalam perkembangannya, Kabupaten Sumedang tumbuh dan mengalami perubahan yang signifikan. Salah satu faktor pendorong perubahan tersebut adalah tumbuhnya sektor industri di Kabupaten Sumedang yang didominasi melalui sektor industri skala kecil, skala menengah dan skala besar. Berdasarkan data tahun 2018 terdapat 913 jumlah perusahaan yang ada di Kabupaten Sumedang. Dengan banyaknya perusahaan yang ada di Kabupaten Sumedang mengakibatkan kompleksitas perselisihan hubungan industrial yang terjadi antara pengusaha dan pekerja/buruh semakin meningkat. Tercatat dari tahun 2016 sampai tahun 2018 terjadi peningkatan perselisihan hubungan industrial di Kabupaten Sumedang yang signifikan. Hal ini terlihat pada grafik di bawah ini :

\section{Grafik Perselisihan Hubungan Industrial di Kabupaten Sumedang Tahun 2016-2018}




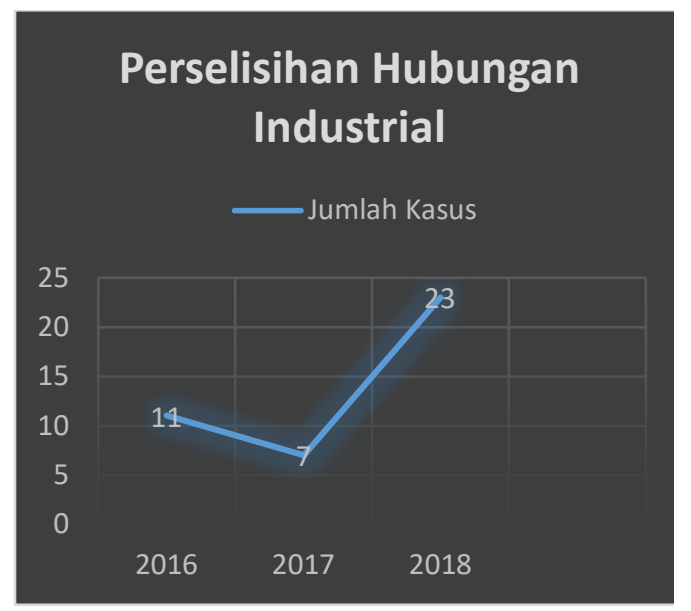

Sumber : Dinas Tenaga Kerja dan Transmigrasi Sumedang Tahun 2019

Berdasarkan kebijakan Peraturan

Menteri Tenaga Kerja dan Transmigrasi Nomor 17 Tahun 2004 tentang Pengangkatan dan Pemberhentian Mediator Hubungan Industrial Serta Tata Kerja Mediasi Pasal 9 menyebutkan bahwa Dinas Kabupaten/Kota adalah instansi yang bertanggung jawab di bidang ketenagakerjaan kabupaten/kota. Dalam melaksanakan tugas sebagaimana dimaksud dalam Pasal 9, disini yang bertanggung jawab atas penyelesaian perselisihan hubungan industrial di Kabupaten Sumedang adalah Dinas Tenaga Kerja dan Transmigrasi Kabupaten Sumedang.
Berdasarkan hasil wawancara awal, penulis menemukan indikasi masalah dalam pelaksanaan kebijakan penyelesaian perselisihan hubungan industrial melalui mediasi di Dinas Tenaga Kerja dan Transmigrasi Kabupaten Sumedang, yang pertama diketahui bahwa tujuan kebijakan penyelesaian perselisihan hubungan industrial melalui mediasi belum terealisasi, dari 23 kasus perselisihan hubungan industrial hanya ada 6 perjanjian bersama (PB) yang dapat diselesaikan melalui mediasi, sisanya 6 perselisihan hubungan industrial lanjut ke Pengadilan Hubungan Industrial (PHI) dan 11 masih bersifat anjuran, dengan kata lain hasil penyelesaian perselisihan hubungan industrial tidak tercapai kesepakatan. Yang kedua tidak adanya jabatan fungsional murni mediator di Dinas Tenaga Kerja dan Transmigrasi Kabupaten Sumedang dan terakhir kurangnya pemahaman dan kesadaran pihak-pihak yang berselisih baik pengusaha maupun pekerja/buruh terhadap 
IMPLEMENTASI KEBIJAKAN PENYELESAIAN PERSELISIHAN HUBUNGAN INDUSTRIAL

MELALUI MEDIASI DI INDONESIA

(STUDI KASUS: KABUPATEN SUMEDANG)

(Friska Prastya Harlis, Herwan Abdul Muhyi, Mohammad Benny Alexandri)

kebijakan Penyelesaian Perselisihan

Hubungan Industrial (PPHI) melalui

mediasi.

Tujuan penulisan artikel ini adalah

untuk mengetahui mengapa implementasi

kebijakan penyelesaian perselisihan

hubungan industrial melalui mediasi di

Dinas Tenaga Kerja dan Transmigrasi

Kabupaten Sumedang belum berjalan

efektif.

\section{TINJAUAN PUSTAKA}

Implementasi kebijakan merupakan

tahapan yang sangat penting dalam

keseluruhan struktur kebijakan, karena

tahapan ini dapat mepengaruhi tingkat

keberhasilan atau pencapaian tujuan dari

proses kebijakan secara keseluruhan. Van

Meter dan Van Horn (dalam Winarno

2014:149) mengartikan implementasi

kebijakan sebagai tindakan-tindakan yang

dilakukan oleh individu-individu (atau

kelompok-kelompok) pemerintah maupun

swasta yang diarahkan untuk mencapai

tujuan-tujuan yang telah ditetapkan dalam keputusan-keputusan

kebijakan

sebelumnya.

Untuk menilai implementasi kebijakan perlu pemahaman mengenai pendekatan dan model apa saja dalam mengukur implementasi kebijakan publik. Pemahaman mengenai pendekatan dan model implementasi kebijakan ini dikaji oleh beberapa ahli. Salah satunya yang dikemukakan oleh Van Meter dan Van Horn. Menurut Donald Van Meter \& Carl Van Horn dalam buku Leo Agustino yang berjudul "Dasar-Dasar Kebijakan Publik (Edisi Revisi)” (2017:133), model implementasi kebijakan yang dikenal dengan istilah "A Model of The Policy Implementation”. Model ini mengandaikan bahwa implementasi kebijakan berjalan secara linier dari keputusan politik yang tersedia, pelaksana dan kinerja kebijakan publik. Ada enam variabel, menurut Van Meter \& Van Horn yang mempengaruhi kinerja implementasi kebijakan publik, diantaranya sebagai berikut : 
a) Ukuran dan Tujuan Kebijakan

b) Sumber Daya

c) Karakteristik Agen Pelaksana

d) Sikap atau Kecenderungan

(Disposition) Para Pelaksana

e) Komunikasi Antar Organisasi dan Aktivitas Pelaksanaan

f) Lingkungan Ekonomi, Sosial dan Poltik
Model implementasi kebijakan dari

Van Meter dan Van Horn ini menunjukkan

bahwa implementasi kebijakan merupakan model yang sangat kompleks dimana satu variabel dapat mempengaruhi variabel lain. Untuk lebih jelasnya dapat dilihat pada gambar di bawah ini :

\section{Model Pendekatan The Policy Implementation Process}

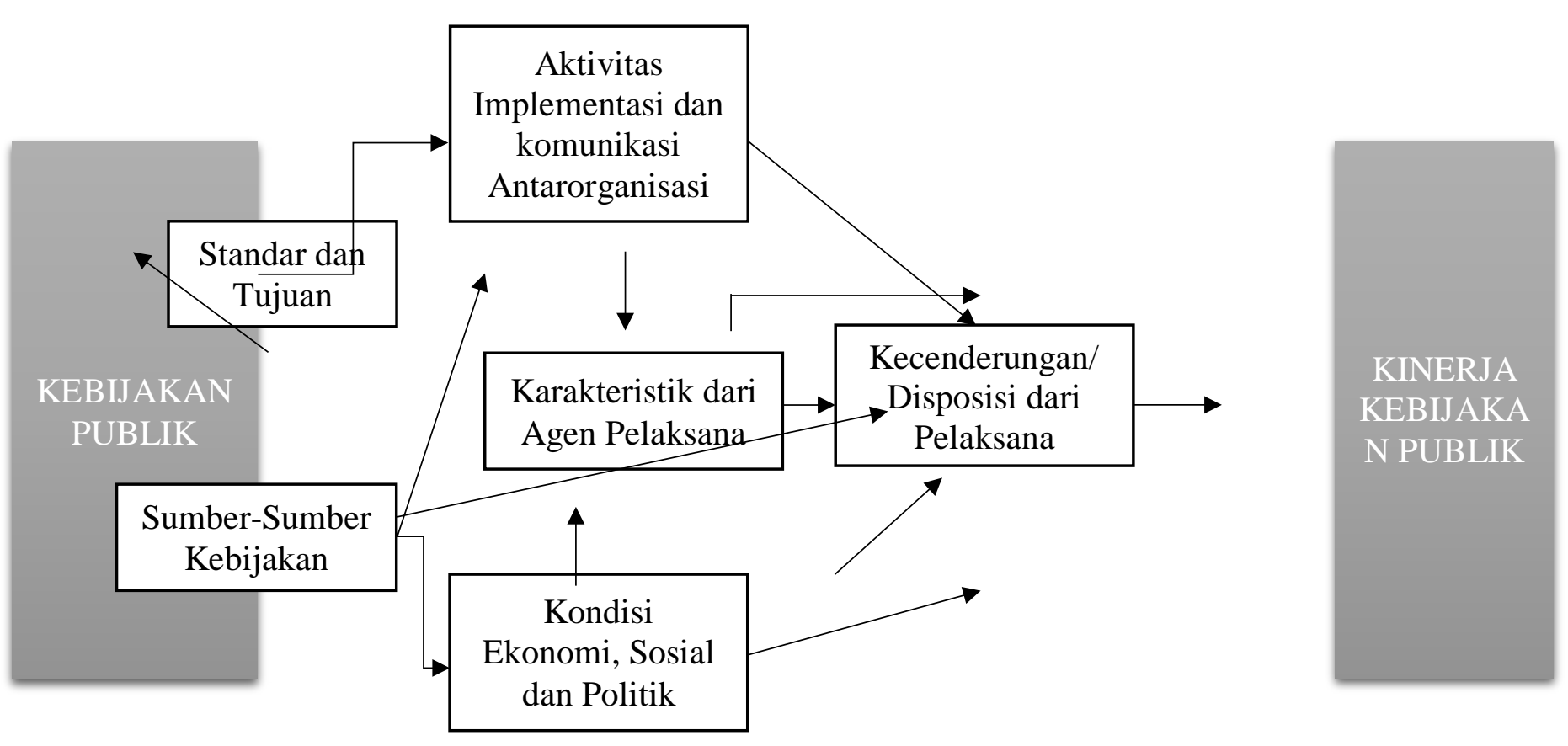

Sumber: Van Meter \& Van Horn (dalam Agustino 2017:136)

Model implementasi kebijakan kebijakan penyelesaian perselisihan

yang ditawarkan oleh Van Meter dan Van

Horn ini menjadi landasan teori di dalam melakukan kajian atas implementasi hubungan industrial melalui mediasi yang

dilaksanakan oleh Dinas Tenaga Kerja dan

Transmigrasi Kabupaten Sumedang. Hal 
IMPLEMENTASI KEBIJAKAN PENYELESAIAN PERSELISIHAN HUBUNGAN INDUSTRIAL

MELALUI MEDIASI DI INDONESIA

(STUDI KASUS: KABUPATEN SUMEDANG)

(Friska Prastya Harlis, Herwan Abdul Muhyi, Mohammad Benny Alexandri)

ini karena adanya relevansi dengan

fenomena kondisi permasalahan yang ada saat ini.

\section{METODOLOGI PENELITIAN}

Dalam penelitian ini penulis menggunakan metode penelitian kualitatif bersifat deskriptif dan cenderung menggunakan analisis dengan pendekatan induktif. Dimana dengan melalui metode kualitatif, peneliti berusaha mencari pemahaman terhadap suatu objek. Teori yang ada akan dikembangkan dengan data yang dikumpulkan.

\section{HASIL DAN PEMBAHASAN}

Kebijakan

penyelesaian

perselisihan hubungan industrial melalui mediasi yang dituangkan di dalam UndangUndang Nomor 2 Tahun 2004 berisikan aspek kelembagaan dan aspek prosedur penyelesaian. Dimana pada aspek kelembagaan telah jelas diatur bahwa lembaga yang dapat melaksanakan kebijakan penyelesaian perselisihan hubungan industrial adalah lembaga ketenagakerjaan. Berikut dengan mediator yang dapat melaksanakan kebijakan penyelesaian perselisihan hubungan industrial melalui mediasi adalah mediator yang berada di instansi ketenagakerjaan. Sehingga dalam melaksanakan kebijakan penyelesaian hubungan industrial tidak dapat sembarang instansi dan mediator.

Ditinjau dari aspek prosedur penyelesaian bahwa penyelesaian perselisihan hubungan industrial ini terlebih dahulu dilakukan melalui perundingan bipartit. Apabila melalui perundingan bipartit tidak dapat terselesaikan maka dapat melalui konsiliasi/arbitrasi/mediasi. Namun apabila pada tahap ini tetap tidak ada kesepakatan antara pihak berselisih maka dilanjutkan menyelesaikan melalui Pengadilan Hubungan Industrial (PHI).

Implementasi kebijakan penyelesaian perselisihan hubungan industrial melalui mediasi pada Dinas Tenaga Kerja dan Transmigrasi Kabupaten 
Sumedang di atur di dalam Peraturan

Menteri Tenaga Kerja dan Transmigrasi

Nomor 17 Tahun $2014 \quad$ Tentang

Pengangkatan Dan Pemberhentian

Mediator Hubungan Industrial Serta Tata

Kerja Mediasi, menjadi pedoman bagi

Dinas Tenaga Kerja dan Transmigrasi

Kabupaten Sumedang dalam melaksanakan

penyelesaian perselisihan hubungan

industrial melalui mediasi di Kabupaten

Sumedang.

UKURAN DAN TUJUAN KEBIJAKAN

Kebijakan

penyelesaian

perselisihan hubungan industrial melalui

mediasi telah jelas bertujuan untuk

menyelesaikan perselisihan hubungan

industrial antara pengusaha dan

pekerja/buruh di luar pengadilan. Sehingga

ukuran standar dari kebijakan penyelesaian

perselisihan hubungan industrial melalui

mediasi adalah keberhasilan penyelesaian

perselisihan hubungan industrial melalui

mediasi. Realisasi tujuan implementasi

kebijakan penyelesaian perselisihan hubungan industrial melalui mediasi pada

Dinas Tenaga Kerja dan Transmigrasi

Kabupaten Sumedang ini pelaksanaannya

belum dapat diselenggarakan secara

maksimal. Hal ini terlihat pada kasus

perselisihan hubungan industrial pada tahun 2018 hanya ada 6 kasus yang dapat diselesaikan melalui mediasi, sisanya ada 11 kasus yang ditangani dengan bersifat anjuran dengan artian tidak ada kesepakatan antara pihak yang berselisih baik pengusaha maupun pekerja/buruh dan 6 perselisihan lainnya lanjut ke tahap Pengadilan Hubungan Industrial (PHI).

\section{SUMBER DAYA}

Sumber daya merupakan salah satu faktor yang penting terhadap keberhasilan implementasi kebijakan publik. Van Meter dan Van Horn (dalam Agustino 2017:134) mengatakan bahwa manusia merupakan sumber daya yang terpenting dalam menentukan suatu keberhasilan proses 


\section{IMPLEMENTASI KEBIJAKAN PENYELESAIAN PERSELISIHAN HUBUNGAN INDUSTRIAL MELALUI MEDIASI DI INDONESIA \\ (STUDI KASUS: KABUPATEN SUMEDANG) \\ (Friska Prastya Harlis, Herwan Abdul Muhyi, Mohammad Benny Alexandri)}

implementasi. Dilihat dari aspek sumber daya manusia di dalam pelaksanaan kebijakan penyelesaian perselisihan hubungan industrial melalui mediasi mediator sebagai pelaksana kebijakan di Dinas Tenaga Kerja dan Transmigrasi Kabupaten Sumedang hanya terdapat dua orang dengan merangkap sebagai pejabat struktural. Dengan kata lain di Dinas Tenaga Kerja dan Transmigrasi Kabupaten Sumedang tidak ada mediator jabatan fungsional murni untuk melaksanakan kebijakan. Hal ini mengakibatkan adanya beban tugas yang tidak seimbang yang berdampak terhadap ketidaksesuaian waktu yang ditentukan dalam penanganan penyelesaian perselisihan hubungan industrial melalui mediasi, di dalam Undang-Undang Nomor 2 Tahun 2004 Pasal 10 dengan jelas telah ditentukan bahwa dalam waktu selambat-lambatnya 7 (tujuh) hari kerja setelah menerima pelimpahan penyelesaian perselisihan mediator harus sudah mengadakan penelitian tentang duduknya perkara dan segera mengadakan sidang mediasi. Namun pada kenyataannya, mediator baru mengadakan sidang mediasi lebih dari 7 hari kerja.

Selain dari segi sumber daya manusia, dilihat dari segi sumber daya anggaran dan sumber daya peralatan juga belum memadai. Dengan tidak optimalnya sumber daya yang dimiliki oleh Dinas Tenaga Kerja dan Transmigrasi Kabupaten Sumedang mengakibatkan tidak efektif impelementasi kebijakan penyelesaian perselisihan hubungan industrial melalui mediasi.

KARAKTERISTIK

AGEN

\section{PELAKSANA}

Karakteristik yang dimiliki oleh mediator sebagai pelaksana kebijakan di Dinas Tenaga Kerja dan Transmigrasi Kabupaten Sumedang cenderung memiliki ketegasan dan keberanian yang baik dan memadai, karena kedua mediator juga mempunyai latar belakang keilmuan yang 
sama, berasal dari ilmu hukum sehingga kedua mediator telah jelas mengetahui aturan-aturan dalam pelaksanaan mediasi. Selain itu mediator di Dinas Tenaga Kerja dan Transmigrasi Kabupaten Sumedang telah melaksanakan kebijakan penyelesaian perselisihan hubungan industrial melalui mediasi telah sesuai SOP yang ada.

SIKAP DAN KECENDERUNGAN (DISPOSISI) PARA PELAKSANA KEBIJAKAN

Dari hasil penelitian yang penulis lakukan di lapangan ditemukan bahwa adanya ketidaknetralan disposisi mediator dalam melaksanakan kebijakan penyelesaian perselisihan hubungan industrial melalui mediasi. Adanya keberpihakan kepada salah satu pihak yang berselisih (pengusaha dan pekerja/buruh). Berdasarkan pengamatan yang penulis lakukan karena adanya tekanan dari pihak pekerja/buruh dengan tujuan yang menjadi tuntutan pekerja/buruh dapat terpenuhi. Dengan situasi yang demikian ini baik langsung maupun tidak langsung akan mempengaruhi sikap mediator baik dalam memediasi maupun dalam membuat anjuran.

Dengan adanya dorongan luar yang sering melakukan aksi unjuk rasa, mengakibatkan mediator yang merangkap sebagai pejabat struktural di Dinas Tenaga Kerja dan Transmigrasi Kabupaten Sumedang tidak ingin keadaan hubungan industrial di Kabupaten Sumedang runyam. Untuk mengkondusifkan hubungan industrial di Kabupaten Sumedang seringkali hasil mediasi lebih berpihak ke pekerja/buruh.

\section{AKTIVITAS PELAKSANAAN DAN} KOMUNIKASI ANTARORGANISASI

Berdasarkan hasil wawancara dengan mediator bahwa aktivitas pelaksanaan kebijakan penyelesaian perselisihan hubungan industrial melalui mediasi dirasa telah sesuai dengan Peraturan Menteri Tenaga Kerja dan Transmigrasi Nomor 17 Tahun 2014 


\section{IMPLEMENTASI KEBIJAKAN PENYELESAIAN PERSELISIHAN HUBUNGAN INDUSTRIAL MELALUI MEDIASI DI INDONESIA \\ (STUDI KASUS: KABUPATEN SUMEDANG) \\ (Friska Prastya Harlis, Herwan Abdul Muhyi, Mohammad Benny Alexandri)}

Tentang Pengangkatan Pengangkatan dan

Pemberhentian Mediator Hubungan

Industrial Serta Tata Kerja Mediasi.

Keberhasilan aktivitas pelaksanaan

kebijakan penyelesaian perselisihan

hubungan industrial melalui mediasi dapat

dilihat dari komunikasi yang terjalin.

Komunikasi yang dimaksud diantara

pelaksana kebijakan dengan kelompok

sasaran kebijakan. Berdasarkan temuan di

lapangan bahwa komunikasi antara

mediator dengan pengusaha maupun

pekerja/ buruh belum terjalin dengan

efektif. Hal ini ditandai dengan masih ada

kelompok sasaran yang belum paham

terhadap kebijakan penyelesaian

perselisihan hubungan industrial melalui

mediasi. Kondisi ini karena mediator Dinas

Tenaga Kerja dan Transmigrasi Kabupaten

Sumedang belum mampu melakukan

sosialisasi kebijakan penyelesaian

perselisihan hubungan industrial melalui

mediasi ke seluruh perusahaan yang ada di

Kabupaten Sumedang. Selama ini mediator
Dinas Tenaga Kerja dan Transmigrasi

Kabupaten Sumedang hanya menjangkau sebagian kecil perusahaan yang ada di kawasan Kabupaten Sumedang. Berdasarkan hasil wawancara yang penulis lakukan hal ini karena adanya keterbatasan sumber daya manusia dan sumber daya anggaran yang dimiliki oleh Dinas Tenaga Kerja dan Transmigrasi Kabupaten Sumedang.

\section{LINGKUNGAN EKONOMI, SOSIAL}

\section{DAN POLITIK}

Lingkungan kebijakan merupakan salah satu faktor penting dalam keberhasilan suatu implementasi kebijakan. Keadaan sosial, ekonomi, politik dan dukungan publik suatu kelompok sasaran akan mempengaruhi implementasi kebijakan. Berdasarkan hasil penelitian yang penulis lakukan ditemukan bahwa belum adanya dukungan yang positif baik dari segi lingkungan ekonomi, lingkungan 
sosial dan lingkungan politik terhadap keberhasilan implementasi kebijakan penyelesaian perselisihan hubungan industrial melalui mediasi yang dilaksanakan oleh Dinas Tenaga Kerja dan Transmigrasi Kabupaten Sumedang.

Dilihat dari lingkungan ekonomi, pihak yang berselisih baik pengusaha dan pekerja/buruh masing-masing mempunyai kepentingan yang berbeda sehingga sulit untuk mencapai kesepakatan dalam proses sidang mediasi. Dimana adanya pihak pengusaha yang ingin memberhentikan pekerja/buruh karena dianggap telah melanggar ketentuan perusahaan yang berlaku tanpa memberikan pesangon karena kondisi ekonomi perusahaan, dan ada juga pihak pekerja/buruh terlepas dari melakukan kesalahan atau tidak dia boleh saja diberhentikan tetapi harus diberikan pesangon sebagaimana yang telah diatur di dalam Undang-Undang Nomor 13 tahun 2003 Tentang Ketenagakerjaan.
Dilihat dari lingkungan sosial, seperti telah dijelaskan sebelumnya bahwa adanya unjuk rasa yang dilakukan oleh pekerja/buruh sehingga memberi tekanan terhadap disposisi mediator dalam melaksanakan kebijakan penyelesaian perselisihan hubungan industrial melalui mediasi.

Dan dari lingkungan politik, Di dalam implementasi kebijakan penyelesaian perselisihan hubungan industrial melalui mediasi telah jelas yang dimuat di dalam Peraturan Menteri Tenaga Kerja dan Transmigrasi Nomor 17 Tahun 2014 dijelaskan bahwa mediator secara khusus diatur oleh keputusan menteri tenaga kerja dan transmigrasi namun dalam pelaksanaannya Peraturan Menteri Tenaga Kerja dan Transmigrasi Nomor 17 Tahun 2014 ini berbenturan dengan peraturan daerah dimana pemutasian pegawai merupakan keputusan bupati setempat. Hal ini tak lepas dari adanya kepentingan politik yang ada. 
IMPLEMENTASI KEBIJAKAN PENYELESAIAN PERSELISIHAN HUBUNGAN INDUSTRIAL

MELALUI MEDIASI DI INDONESIA

(STUDI KASUS: KABUPATEN SUMEDANG)

(Friska Prastya Harlis, Herwan Abdul Muhyi, Mohammad Benny Alexandri)

KESIMPULAN

Implementasi

kebijakan

penyelesaian perselisihan hubungan

industrial melalui mediasi yang dilakukan

oleh Dinas Tenaga Kerja dan Transmigrasi

Kabupaten Sumedang belum berjalan

efektif karena belum terpenuhinya variabel

ukuran dan tujuan kebijakan, sumber daya,

karakteristik agen pelaksana, sikap para

pelaksana, aktivitas implementasi dan

komunikasi antarorganisasi dan lingkungan

ekonomi, sosial dan politik dalam

implementasi kebijakan.

\section{SARAN}

1. Untuk berhasilnya Implementasi

Kebijakan Penyelesaian Perselisihan

Hubungan Industrial melalui mediasi

yang dilaksanakan oleh mediator maka

mediator di Dinas Tenaga Kerja dan

Transmigrasi Kabupaten Sumedang

menyelenggarakan

sosialisasi/pemahaman prosedur dan

tata cara khususnya kebijakan

penyelesaian perselisihan hubungan industrial melalui mediasi yang dapat

menjangkau/diikuti oleh semua

perusahaan dan atau serikat

pekerja/pekerja yang ada di wilayah

Kabupaten Sumedang.

2. Setelah Dinas Tenaga Kerja dan

Transmigrasi Kabupaten Sumedang

menerima pendaftaran/pencatatan

perselisihan hubungan industrial

mediator kiranya dapat mendatangi

para pihak yang berselisih sebelum

membuat/melayangkan surat panggilan

untuk dimediasi.

3. Dinas Tenaga Kerja dan Transmigrasi Kabupaten Sumedang menghindari seorang mediator rangkap jabatan dengan cara mengisi jabatan mediator tersebut yang bekerja sama dengan SKPD Kabupaten Sumedang untuk bisa menempatkan ASN yang telah memenuhi persyaratan kompetensi mediator dalam penyelesaian perselisihan hubungan industrial. 
4. Kementerian Tenaga Kerja dan

Transmigrasi Republik Indonesia harus memperhatikan besaran anggaran khususnya terhadap operasional kebijakan penyelesaian perselisihan hubungan industrial.

5. Mediator Dinas Tenaga Kerja dan Transmigrasi Kabupaten Sumedang harus tetap bisa menjaga kenetralan baik dalam pelaksanaan mediasi maupun mengeluarkan anjuran sekalipun menghadapi situasi kondisi yang sifatnya tekanan dari khususnya dari pihak pekerja/buruh.

\section{DAFTAR PUSTAKA}

\section{$\underline{\text { BUKU }}$}

Agustino, Leo. 2006. Dasar-Dasar

Kebijakan Publik. Bandung: CV. Alfabeta. . 2017. Dasar-Dasar

Kebijakan Publik. Bandung: CV. Alfabeta. Anggara, Sahya. 2018. Kebijakan Publik. Bandung: CV. Pustaka Setia.
Arikunto. 2006. Prosedur Penelitian Suatu

Pendekatan Praktek. Jakarta: PT. Rineka

Cipta

Bambang, R Joni. 2013. Hukum

Ketenagakerjaan. Bandung: CV. Pustaka

Setia.

Hoogerwarf, H. 1983. Ilmu Pemerintahan. Jakarta: Erlangga.

Hood, C. Cristopher. 1978. The Limit Of

Administration. John Willey \& Son.

Husni, Lalu. 2016. Pengantar Hukum

Ketenagakerjaan. Jakarta: PT.

RajaGrafindo Persada.

Khakim, Abdul. 2014. Dasar-Dasar

Hukum Ketenagakerjaan Indonesia.

Bandung: PT. Citra

Aditya Bakti.

Margono, Suyud. 2004. Alternative

Dispute Resolution dan Arbitrase Proses

Pelembagaan

Dan Aspek Hukum. Bogor:

Penerbit Ghalia Indonesia. 
IMPLEMENTASI KEBIJAKAN PENYELESAIAN PERSELISIHAN HUBUNGAN INDUSTRIAL

MELALUI MEDIASI DI INDONESIA

(STUDI KASUS: KABUPATEN SUMEDANG)

(Friska Prastya Harlis, Herwan Abdul Muhyi, Mohammad Benny Alexandri)

Moleong, Lexy. 2004. Metode Penelitian

Kualitatif. Bandung: PT. Remaja Rosda

Karya.

Purwanto, E. A dan Dyah Ratih

Sulistyastuti. Implementasi Kebijakan

Publik Konsep dan

Aplikasinya Di Indonesia.

Yogyakarta: Penerbit Gava Media.

Rusli, Budiman. 2013. Kebijakan Publik

Membangun Pelayanan Publik Yang

Responsif.

Bandung: Hakim Publishing.

Sediawati, Diani. 2011. Efektivitas

Penyelesaian Sengketa Lingkungan Hidup

Di Indonesia.

Jakarta: Bappenas.

Subarsono. 2015. Analisis Kebijakan

Publik. Yogyakarta: Pustaka Pelajar.

Sugiyono. 2009. Metode Penelitian

Kuantitatif, Kualitatif dan R\&D. Bandung:

Alfabeta.

. 2013. Metode Penelitian

Kuantitatif, Kualitatif dan R\&D. Bandung:

Alfabeta.
Tachyan. 2006. Implementasi Kebijakan

Publik. Bandung: AIPI.

Uwiyono, Aloysius dkk. 2014. Asas-Asas

Hukum Perburuhan. Jakarta: PT.

RajaGrafindo

Persada.

Widodo, Joko. 2018. Analisis Kebijakan

Publik. Malang: Media Nusa Creative.

Wijoyo, Suparto. 2003. Penyelesaian

Sengketa Lingkungan (Enviromental

Disputes.

Resolution). Surabya: Penerbit

Airlangga University Press.

Winarno, Budi. 2014. Kebijakan Publik. Jakarta: PT. Buku Seru.

\section{Perundang-Undangan}

Undang-Undang Dasar Negara Republik Indonesia Tahun 1945

Undang-Undang Nomor 16 Tahun 1951 Tentang Penyelesaian Perselisihan Perburuhan

Undang-Undang Nomor 22 Tahun 1957 Tentang Penyelesaian Perselisihan Perburuhan

Undang-Undang Nomor 13 Tahun 2003 Tentang Ketenagakerjaan 
Undang-Undang Nomor 2 Tahun 2004 Tentang Penyelesaian Perselisihan Hubungan Industrial

Instruksi Menteri Perburuhan No. PBU.1022-45/U.4191 Tentang Penyelesaian Perselisihan Perburuhan

Peraturan Kekuasaan Militer Tentang Penyelesaian Pertikaian Perburuhan

Peraturan Menteri Tenaga Kerja dan Transmigrasi Nomor 17 Tahun 2014 Tentang Pengangkatan dan Pemberhentian Mediator Hubungan Industrial Serta Tata Kerja Mediasi

Peraturan Daerah Kabupaten Sumedang Nomor 9 Tahun 2014 tentang pembentukan Organisasi Perangkat Daerah Kabupaten Sumedang Dinas Sosial dan Tenaga Kerja dan Transmigrasi Kabupaten Sumedang

Peraturan Bupati Sumedang Nomor 11 Tahun 2017 Tentang Uraian Tugas Jabatan Struktural Pada Dinas Tenaga Kerja dan Transmigrasi

\section{Disertasi dan Jurnal}

Amirizal. 2016. Prinsip Mediasi Sebagai Dasar Metode Alternatif dan
Konseptualisasi Asas Hukum Penyelesaian Sengketa Perikanan di Indonesia Dalam Rangka Pembangunan Hukum Nasional. Bandung: Universitas Padjadjaran.

Curran, Deidre. 2014. The Role Of Mediation In The Resolution of Two Industrial Disputes In Ireland: Towarda A Theoretical Understanding. Employee Relation. Vol. 36, No.05.

Hernawan, Ari. 2011. Hukum dan Kekuasaan Dalam Hubungan Industrial. Mimbar Hukum. Edisi Khusus.

Lipsky, David B, Ariel C Avgar. 2016. Resolving Workplace Conflicts Through Litigation: Evidence, Analysis and Implications. Advances in Industrial and Labor Relations. Vol. 22.

Roche, William K, Colman Higgins. 2016. Networked Dispute Resolution: The National Implementation Body in Irish Industrial Relations. Advances in Industrial and Labor Relations. Vol. 22.

Yetniwati, Hartati, Meriyarni. 2014. Reformasi Hukum Penyelesaian Perselisihan Hubungan Industrial Secara Mediasi. Jurnal Dinamika Hukum. Vol.14, No.02. 